\title{
Exploring Narrative Ideas in Career Counseling
}

\author{
Andronikos Kaliris, Philia Issari \\ Department of Psychology, National and Kapodistrian University of Athens, Athens, Greece \\ Email: issariph@psych.uoa.gr, akaliris@ppp.uoa.gr
}

How to cite this paper: Kaliris, A., \& Issari, P. (2022). Exploring Narrative Ideas in Career Counseling. Open Journal of Social Sciences, 10, 365-380.

https://doi.org/10.4236/jss.2022.102026

Received: January 26, 2022

Accepted: February 22, 2022

Published: February 25, 2022

Copyright $\odot 2022$ by author(s) and Scientific Research Publishing Inc. This work is licensed under the Creative Commons Attribution International License (CC BY 4.0).

http://creativecommons.org/licenses/by/4.0/

\begin{abstract}
Today, grounded on the turbulent conditions of the social and work environment as well as the unstable life and career paths individuals are going through (Guichard, 2015; Savickas, 2015), incorporating constructivist-narrative methods and techniques in career counseling seems essential, at least in some client cases. Narrative approaches could support the identification of an individual's meaning-making process and have the capacity to face clients holistically with respect to career development issues. The aim of this article is to provide a brief review of several influential narrative approaches in career counseling that emerged in the last two decades. A second goal of this work is to highlight fundamental strengths of narrative career counseling approaches, showcasing their benefits in counseling practice, especially in promoting the construction of a robust and solid autobiographical career narrative.
\end{abstract}

\section{Keywords}

Constructivist-Narrative, Constructionist, Postmodern, Career Counseling Interventions, Meaning-Making, Context, Autobiographical Career Narratives

\section{Introduction}

The traditional, positivist career development theoretical approaches have been employed in counseling practice for more than half a century, aiming primarily at the best possible matching between the individual and the work environment, so that both workers and employers get satisfied (Hartung \& Santilli, 2018). Over the last 120 years, the "quantitative-psychometric" paradigm has dominated the career counseling field (McIlveen et al., 2003), having its roots in the industrial period and cultivated through the wider scope of counseling psychology in the United States (Malikiosi-Loizos, 2017). During the industrial period (1900-1950) many job vacancies were offered. Working environments were quite 
predictable while the model "person-environment" characterized by an ideal fit between job seekers and existing jobs served the purpose of preparing employees for stable workplaces. These early theories (e.g. Parsons' trait-and-factor approach, Holland's typology) are still dominant in the career guidance and counseling field. Over the years career development theories incorporated additional interesting elements such as salience of dominant roles in an individual's life, also adopting a rather developmental perspective.

Many aspects in traditional positivist theories tend to employ, for instance, results of personality or interest questionnaires, in many cases still remain relevant and appropriate (e.g. taking decisions on academic major after senior high school). However, career development no longer occurs in a stable and linear world of work; rather, the notion of career may be defined by the metaphor of an "unpredictable journey", including several highways and byways. Today career is conceived as a subjective quality referring not only to occupations but further life roles as well (Savickas et al., 2009).

Some parameters may be neglected or masked in earlier traditional approaches that focus on analyzing static traits and matching them with specific work environments. A pervasive trend in critiques of career psychology relates to a perception that its main focus is the western white middle class and that traditional career counseling practice may not be appropriate for minorities, women and other special populations; while the mainstream theories and techniques may not apply across countries and cultures (McMahon, 2018; cf. McMahon, 2014).

Thus, some authors have contended that career counseling should reduce its positivist and individualist focus towards research and practice and address inequities through a social justice lens in theory development (McMahon, 2014). New emerging theories based on constructivism and social constructionism seem more aligned with these new purposes for the career counseling field. Moreover, current socioeconomic variability challenges the completeness of most career development theories of the last century, resulting in the development and redevelopment of career assessment and counseling models (Watson, 2016).

It is widely accepted that although earlier psychometric interventions are still relevant and effective, especially when the goal is set to help a person choose among various options of studies and occupations, they do not seem appropriate in empowering individuals through transition phases (Savickas, 2015). Moreover, traditional psychometric approaches are not that sensitive in assessing subjective or phenomenological dimensions in individuals, including lived experiences which affect career development (Maree, 2015). Finally, some professionals have concerns about the negative effects of possibly unreliable test profiles in career counseling and guidance practices (Maree, 2015). Guichard (2018) suggests that today, in order to provide effective services to clients, counselors should help them realize what they want and what they can become, by helping 
them attribute meaning to their experiences.

The article focuses on recent postmodern approaches (third wave of career counseling interventions) which support the idea of formulating human knowledge and meaning through a constant interaction between individual and society (Hartung \& Santilli, 2018). More specifically, through this work the authors will attempt to highlight the importance of Narrative Career Counseling providing a brief and targeted overview of some of the most influential narrative approaches in the field that emerged in the last two decades. From our point of view, these theoretical approaches should not replace the traditional ones but rather complement them for the best interest of the clients. Another goal of this paper is to pinpoint fundamental strengths of narrative career counseling approaches, showcasing their benefits in counseling practice. It concludes with recommendations on utilizing narrative career counseling theories in practice to help clients realize solid autobiographical career narratives in real life.

\section{Narrative Turn in Career Counseling}

New trends in theory development in career counseling could, at least to some extent, be conceptualized as "responses to the questions generated by critiques of career psychology and massive changes in society as a result of globalization and dramatic changes in technology" (McMahon, 2014: p. 18). Constructivism and social constructionism have provided responses to societal change. While constructivism places emphasis on individuals' cognitive processes social constructionism supports that human action and interaction are constructs that are being formed through social mediations (Gergen, 1985). These philosophical foundations may have greater capacity to accommodate the complex and dynamic processes of a rapidly changing society than theories that reflect a positivist perspective. Constructivist worldview can address clients' complex needs in practice. Such a perspective serves as the conceptual background of the narrative paradigm in career theory and interventions.

Narration is at the core of narrative counseling theories. Narratives, which are either oral, written or mixed in a later phase, constitute an old cultural tool which historically appeared when people became aware of the importance of stories in describing their thoughts and emotions. Narratives do not only reflect reality but also create it, by providing individuals with the ability to give meaning to their experiences (Bruner, 2002). Meanings, which are generated from life stories are constantly changing, depending on individuals' action framework. Consequently, it seems that there is not only a sole scope of reality, but multiple ones. Moreover, there is not only one way to think, act and feel (Kriwas, 2011).

The narrative approaches of career counseling followed the narrative turn in the wider field of counseling psychology (Issari \& Karayianni, 2013; McLeod, 2003) which reflects the shift from collecting information about clients to assisting them in generating experiences through their stories. In narrative approaches self is regarded as an a posteriori structure which has been constructed (and construed) through an individual's narratives (self-construction). According to 
narrative epistemology, self does not emerge from pre-existing static traits. This view denotes a transition from the psychometric to the narrated self (Issari, 2011). On the other hand, it highlights the importance of subjectivity, various perspectives, multiple truth, as well as the interpretation of human action, in addition to its "objective"/quantitative measurement (Kaliris \& Kriwas, 2014).

Narrative Career Counseling (NCC) could be understood as a support process for the individual while they are trying to present their life story as a whole. Personal stories that people share with the career counselor are vital as they help them envision the future, integrating experiences of the past and the present in order to formulate future prospects (McMahon \& Watson, 2012). The main goal of NCC is to get counselees involved in a reflective play in which they could pursue a more satisfactory life and career identity (Reid \& West, 2011). Thus, in such an approach, various aspects of career are perceived as constructs, consisting of both personal meaning-making and interaction between the person and the socio-cultural context. In NCC, counselees are supported to develop themes and meanings as well as to reform past constructs based on the description of their career experiences in co-operation with the counselor (Del Corso \& Rehfuss, 2011). Counselees are considered to be experts on the issues concerning their lives (Bujold, 2004) whereas counselors are supposed to facilitate the development of the counselees learning experiences as well as to co-construct relative meanings.

The counseling process consists of three main phases: De-construction, Co-construction, and Re-construction. In the phase of De-construction, counselee's narrative for a career theme is revealed. The client's story is heard carefully by the counselor and the experiences are utilized in order to reveal important information regarding the person. Narrative is examined by both sides (client-counselor) and well-established behavior schemes as well as issues tightly connected with the problem expressed by the person, are confined. Through a deeper exploration both sides attempt to deconstruct those schemes and all the relative issues. In the phase of Co-construction the ability of providing multiple different interpretations of the same themes is emerged. This process aims to enable the counselee in viewing relative issues and themes from another, more flexible perspective. Then, an attempt for a new reality to be co-constructed occurs. Finally, in the phase of Re-construction counselee narrates the story related with the problem once more albeit including a future perspective this time. Themes, necessary to be developed, are identified, as well as some others, which should be attributed less importance in the future.

In the next section follows an overview of selected narrative-constructivist career counseling approaches that have had an impact in our field and can be translated into effective interventions, for various ages and populations. The richness of their epistemological underpinnings along with the variety of tools they utilize can enhance reflection, raise self-awareness and help clients set meaningful goals for their future. At the centre of all different narrative career development theories is the attempt to describe the dynamic complexity of indi- 
viduals' life and career paths (Rossier et al., 2021). Although it is not under the scope of this paper to describe all of the existing approaches, the authors have picked out a number of them with the aim of outlining their essential elements. A detailed account of each theory is not possible within the scope of this paper but it is available in the included references to the theories.

\section{Examples of Narrative Career Counseling}

\subsection{The Foundations of Narrative Career Counseling: Cochran's (1997) Approach}

Cochran (1997) developed the foundations for a narrative approach to career counselling based on previous work (Cochran, 1990; Watkins \& Savickas, 1990). According to Cochran (1997) career decision-making difficulties result from individuals' experience of the gap or tension between their actual and their desired career positions. Continuous and coherent career narratives can be formulated and adopted by individuals in their constant attempt to resolve such a gap and actualize an ideal future life and career narrative.

Fundamental role in his theory play the standards of wholeness, harmony, agency, and fruitfulness. Clients elaborate career options sustained in a coherent life story (wholeness). The particularities of the work role envisioned or desired (e.g., the setting and hours and the kind of house one can afford) should fit harmoniously with particularities of other career roles (harmony) in order to safeguard balance in life. Furthermore, in this process, clients should emerge as active agents striving to overcome the barriers to their purpose (agency) whereas enthusiasm and joy are essential to face future challenges (fruitfulness). However, the adoption of a narrative regarding career choice and development would be ineffective without applying certain attitudes and behaviors (practical wisdom) that enable individuals to face career challenges.

\subsection{Sociodynamic Counseling (Peavy, 1997, 2000)}

Sociodynamic Counseling (Peavy, 1997, 2000) is a holistic approach formed under the influence of constructivism. According to Peavy (2000), most human problems are characterized from notions of uncertainty and complexity and also self, relationships, organizations, societies and cultures are socially constructed. In the core of this approach is the client's life space; thus, counselor uses narratives in order to explore it. In essence, the client explores his/her personal existence in which work stands as a core subsystem. Meaning-making with regard to certain career experiences and relationships with other individuals are also examined. In this framework it is considered crucial to a person both to pursue important goals and participate successfully in social life.

The "narrated self" is another fundamental notion of Sociodynamic Counseling referring to people's tendency to narrate multiple selves. These selves are evolving, interrelated and subject to constant narration. Clarification of those various dimensions (voices) of the polyphonic self is accomplished through ei- 
ther written or oral narration, dialogue, mapping as well as metaphors. Finally, the whole process results in decision making and co-construction of future plans.

\subsection{The Storied Approach to Career Counseling (Brott, 2001)}

Brott's (2001) Storied Approach to career counseling was based upon the proposition that a person's identity is bound up in his or her life story which inherently speaks of career. Its constructivist theoretical foundations are aligned with the life themes and developmental features of the Career Construction Theory (Savickas, 2005). The process of the Storied Approach involves the essential phases of co-construction, deconstruction, and construction, that is, respectively, to reveal, unpack, and then re-author (Brott, 2001, 2004). This process entails a dynamic and intrinsically interwoven interchange between client and counselor through which information is combined to form a story for the client.

During co-construction, the counselor and client reveal the stories from the past and present. Deconstruction involves unpacking stories and seeking differing perspectives; a process that embeds the client's story in context, encourages flexibility, and produces distinctive meaning that enhances potential and aspiration. The re-authoring phase involves the construction of new stories, which is a process throughout which the counselor supports and poses questions to draw the story into the broader elements of the client's life. In addition to the interview process, Brott endorsed the use of qualitative and quantitative assessment procedures (e.g., card sorts and psychometric interest inventories), but emphasized that their use was for the construction of meaning rather than vocational diagnosis (McIlveen \& Patton, 2007).

\subsection{Life Design (Savickas, 2012; Savickas et al., 2009)}

Savickas's compelling career construction theory, which is built on new ideas from constructionist narrative psychology, formed a key foundation for Life-design theory (Blustein et al., 2019). Within the life-design movement (Savickas et al., 2009) a focus has been advanced for the integration of work and nonwork issues in the development of a holistic approach to career development and career counseling. The life design approach uses clients' stories and narratives to understand how they view themselves and events around them to create a career path for the future (Savickas, 2019). This life-long and holistic model for career counseling practice combines notable contributions from both the Life-long Self-Construction theory (Guichard, 2005, 2009) and the Career Construction theory (Savickas, 2005, 2006). The combination of these two career counseling theoretical approaches has culminated in a rich paradigm that expands the purview of career counseling to include a broader focus on designing one's life across roles and the life span (Blustein et al., 2019).

According to Savickas (2012), career is constructed from small stories which afterwards get re-constructed through the counseling process. At a final stage, 
counselor and client co-construct future plans in which counselee's career story evolves to a new episode that takes place within the actual world. It is very important to Life Design theory that people design their lives in a holistic way in order to gain a sense of satisfaction. Furthermore, Life Design highlights the significance that flexibility, employability and life-long learning have for the individuals' career development.

Counseling intervention goes through 6 fundamental stages including narrative forming and dialogue, small life stories and meanings the client gives to their experiences which are re-constructed to a new narrative whereas several possible subjective selves begin to develop. Counselor and client co-operate to compose both the former self and the new self formed through counseling. At later stages, the counselee practices new roles in which a new, more satisfactory identity becomes fulfilled.

Life design theory has received widespread international attention and has inspired multiple studies that have validated a key measure, the Career Adapt-Abilities Scale-CAAS (Savickas \& Porfeli, 2012), across multiple international contexts. An excellent meta-analysis on this topic is provided by $\mathrm{Ru}$ dolph et al. (2017). In the Greek context, CAAS was validated using a sample of 452 university students, supporting the original 4 -factor structure (Sidiropoulou-Dimakakou et al., 2018).

\subsection{Systems Theory Framework of Career Development (Patton \& McMahon, 2014)}

A promising trend points to the emergence of nonlinear theories of career development and vocational behavior. Systems Theory Framework-STF (Patton \& McMahon, 2014) was developed in response to calls for theoretical integration and quickly emerged as a vital and promising contribution that emphasizes the recursive nature of psychosocial causality (Blustein et al., 2019). Unlike other theory developments in career counseling the STF can be viewed as a metatheoretical framework rather than a theory and it is the first such framework proposed in the field (McMahon, 2014). It encompasses a broad array of content and process influences, including intrapersonal factors (e.g., psychological attributes, attitudes, beliefs, values, personality, interests, disability, and sexual orientation) and environmental, societal content influences (e.g., political, economic, and historical factors). This systemic framework of interconnected influences aims to capture the complex reality of work-based decisions and behaviors (Blustein et al., 2019).

More specifically, the main hypothesis articulated at STF (Patton \& McMahon, 2014) is that individuals are located within multiple systems of influence (personal, social and environmental) which constantly interact with each other and also with the individuals. Each of those systems incorporates a broad variety of influences such as values, interests, social groups and the labor market (McMahon \& Watson, 2012). Thus, STF draws attention to the facilitation of the client's meaning making process through the exploration of these multiple ca- 
reer related systems (McIlveen \& Patton, 2007). At the core of this theoretical development is the assumption that individuals construct stories while going through a process of constant interaction with those systems, which help them generate meaning from their experiences.

Although theories framed under the logical positivist paradigm have provided detailed accounts of many of the extant influences [e.g. Holland (1997) has explained through his theory the role of different personality types in career choices) other constructs, such as disability and sexual orientation have not been well captured in career counseling. On the other hand, STF is advantageous and powerful in that, it considers how such influences may be accounted for by subjective narrative accounts told by the individual themselves. Most importantly, STF, in contrast to other theories, has the ability due to its metatheoretical orientation to accommodate special influences on career development such as that of socioeconomic disadvantage on career development (McMahon, 2014). Narrative is vital at that type of career counseling intervention because it reinforces a sense of connectedness between clients and their stories about past, present and future. In practice, STF is applied through a story telling approach which encourages people to identify and narrate stories that relate with important career influences and themes (McMahon \& Watson, 2010).

Two well-known instruments often used in applying the Systems Theory Framework of Career Development are the "Career Systems Interview" (McIlveen et al., 2003) and "My System of Career Influences" (McMahon et al., 2005). Both instruments could support the counselor and the client to address the interaction points among several influences. As a result, the process gets completed when specific action plans are provided to the client.

\subsection{Chaos Theory of Careers (Bright \& Pryor, 2011; Pryor \& Bright, 2019)}

Chaos Theory of Careers-CTC (Bright \& Pryor, 2011; Pryor \& Bright, 2019) is another recent compelling contribution in career counseling that represents nonlinear dynamics in career development. It borrows many aspects from Chaos theory as used in exact sciences (Peake \& McDowall, 2012). A central assumption of this theory is that career and work-based processes are highly complex and very difficult to predict given the presence of chance factors and other unexpected events that play a significant role in the career course (Blustein et al., 2019). Interestingly, Pryor and Bright have argued that "chance events occur more frequently than individuals imagine" (McMahon, 2014: p. 19).

Individuals and frameworks in which their careers evolve (labor market, organizations, social groups) are perceived in CTC as complex systems that constantly function under influences of both stability and change (Bright \& Pryor, 2011). Although the use of the term "chaos" may imply a lack of order or coherence in one's career life; several patterns can be discerned if nonlinear perspectives are sought that incorporate chance and broad systemic influences (Blustein et al., 2019). Constructivism proposes that individuals look for patterns while 
interpreting their life and career trajectories. In CTC, looking for patterns of behavior in complex systems is termed "emergence" which in turn facilitates meaning making (McMahon, 2014). Due to unpredictability of such complex personal and contextually embedded systems Bright and Pryor (2011) have argued that individuals are well placed to actively create their futures.

"Attractors" stands as another important term in CTC. Attractors tend to constrain functioning in some way by influencing behavior towards particular directions. Therefore, behavior may focus on goals (point attractors), move between two points (pendulum attractors), progress through a series of habitual steps (torus attractors), or demonstrate stability over time but also the possibility of change (strange attractors).

Overall, CTC aims to facilitate clients to get prepared to confront changes and utilize them for their benefit (McIlveen, 2009). Hence, counselor and client attempt to maintain a feeling of optimism even against chaotic situations. Profoundly, this presupposes a shift on counseling theory and practice from probability thinking to the discovery of person's strengths (Pryor et al., 2008).

Chaos theory of careers relies on narratives and metaphors since they are crucial to the identification and the interpretation of client's "fractals" (personal schemas) in multifaced ways. Various instruments have a complementary role as they could be used to boost creative thinking and alertness in the face of unanticipated situations. Psychometric tools are also useful in supporting comparisons between fractals of the client and others.

\section{Strengths of Narrative Career Counseling Approaches}

Narrative approaches of career counseling present plenty of advantages for the counseling practice. Of course, there are also certain limitations associated with their use; however, an analysis of their drawbacks is out of the scope of this work (the interested reader on that topic is advised to look at related readings such as Di Fabio, 2014; Stebleton, 2010). In the following lines there is an attempt to summarize the main strengths of the narrative theories both in terms of thoroughness and quality of their conceptual framework and the implications they may provide for career counseling practice.

\subsection{Emphasis on Context}

In contrast with the common views of positivist career development theories, one of the most important advantages of narrative career counseling theories is the emphasis they place on the context through which individuals make career decisions, plan and manage their life and career. Various contexts (family, community, relationships, society, economic trends and so forth) are according to approaches such as STF or Chaos Theory of Careers, in constant interaction with people's career trajectories and decisions. The influences of context are fully articulated and reflected through clients' stories. Particularly in narrative career counseling individuals are treated as storied beings instead of only as holders of 
static traits like skills, interests, or values (Di Fabio, 2014; Kaliris \& Kriwas, 2014). Narrative career counseling acknowledges that situations occurring in people's lives are complex. This implies that the person-environment fit framework cannot be applied without considering, in addition, people's lives, trajectories, and stories (Rossier et al., 2021).

\subsection{Constructing Coherent Autobiographical Career Narratives}

People have to navigate in different contexts, adopt different roles, evolve over time, and link their inner life with the way they aim to be in the world. These dynamics develop in three directions (inner life, different roles, over time), which individuals must articulate in a meaningful manner in order to structure a continuous self-concept. This process preserves a feeling of integrity (Rossier et al., 2021). Generating reflections about experiences and influences of the past and the present in relation with the vision of desired future selves represents a fundamental aim of narrative career counseling interventions. Thus, clients are empowered to construct a robust and solid autobiographical career narrative through a continuous re-authoring process (McMahon et al., 2019).

Narratives do not necessarily recount chronological tales; they talk about episodes and events. These events are related to the individuals' psychosocially constructed view of themselves in the world; and biographical patterns begin to emerge. Identifying patterns, what can be "seen" in a story, can be a starting point to identify broader life themes and career interests. The aim for the clients is to identify these life and career themes for themselves. One of the strengths of the narrative approach is that within the process there is an opportunity for clients to hear the advice they give to themselves in the stories they tell (Savickas, 2012). This is achieved through the articulation of role models, characters in favorite stories, and early recollected stories (Reid \& West, 2014).

The ultimate goal is to formulate satisfactory identities for the future capitalizing on a sense of connectedness between past and present stories and influences. Clients in cooperation with counselors move through the phases of deconstruction and co-construction to extract subjective experiences and important meanings attributed to career and life. In the phase of reconstruction new fruitful roles that clients want to play in real life are formulated. The power of narration lies on that it allows people to link their inner and their social evolving experiences into a coherent whole.

\subsection{Meaning-Making as a Tool for Promoting Change}

The narrative turn in career counseling encourages interventions to focus more on the meaning experiences, the reflexive processes involved, and the contextual aspects of career paths. Almost every narrative career counseling approach shares some or all of the above elements (see for instance, Systems Theory Framework, The Storied Approach, Life Design). Through narration clients do not only tell a story (or stories) but also attribute specific meanings to them. This 
helps them build a narrative identity through a dialogical relationship with the counselor, consequently, situating themselves in social space.

The meaning-making activity is central to all narrative career counseling approaches. In such interventions, meaning-making is an important function which is tightly linked with self-representations. Although information processing is very important for career choices and career development, narrative approaches emphasize, in addition, the importance of people's self-representations, which emerge in a constant interaction with their context, career stories, identity development, or meaning of life and work (Busacca \& Rehfuss, 2017).

A meaning-making process also allows people to make sense of their life paths (Ibarra \& Barbulescu, 2010). This narrative activity sustains the development of the self-concept and identity throughout time. The ability to narrate our lives, a meaning-making activity, also fosters agency by creating links among past, present, and future with continuity and coherence (Rossier et al., 2021). This activity, in turn, also helps linking and structuring the different layers of our self-representations in their dialogical interactions with our environment (Guichard, 2009).

In the postmodern world, the notion of choice may be substituted by the notion of change, which implies a continuous series of choices. Promotion of reflexive meaning-making processes reinforces real changes in clients' lives, since when one narrates his/her life also fosters agency by promoting intentionality, towards future goals and actions (Hartung, 2015; Rossier et al., 2021).

\section{Conclusion}

The authors intended to provide a brief overview of some important narrative approaches in career counseling that emerged in the last 20 years; starting from Cochran's early narrative approach and moving towards more complex theories such as Systems Theory Framework of Career Development and Chaos Theory of Careers. Such theories and their related tools and applications have evolved and developed in tandem with the reformulation of work environments, society and economy; and emerged as a response to the complexity of the needs of individuals in career and life planning. The aforementioned approaches also stem from the profound realization that clients are active agents who live, work, form their identities and envision future careers in constant interaction with their contexts; therefore, they cannot be viewed only as a sum of their traits that should be matched with ideal jobs. Rather, they are thought as human beings searching for personal meaning through the formation of new satisfactory career and life themes.

Another goal of this work was to highlight fundamental strengths of narrative career counseling approaches especially in terms of benefits for the counseling practice. Examination of the relevant literature shows that positioning clients in their context and investigating relevant interrelations, generating meaning-making and using it as a tool for promoting change in client's life as well as constructing 
coherent autobiographical career narratives through stories may serve as the core advantages of such approaches. From our point of view, the latter element might have been the greatest contribution of narrative interventions both at conceptual and practical level. More specifically, if clients are supported to imagine roles that fulfill their multiple identities, which are in accordance with the dominant career and life themes of the past and the present, they can also be able to make meaningful decisions with respect to what they truly want to be in the future. However, further conceptual and empirical research should be conducted in the next years concerning the effectiveness and potential of narrative career counseling approaches in various groups (students, workers, people in transitions, unemployed etc.) to reveal under what specific circumstances and for what kind of populations such postmodern approaches may be more beneficial for clients in our times.

\section{Funding}

This research is co-financed by Greece and the European Union (European Social Fund, ESF) through the Operational Programme "Human Resources Development, Education and Lifelong Learning" in the context of the project "Reinforcement of Postdoctoral Researchers, 2nd Cycle" (MIS-5033021), implemented by the State Scholarships Foundation (IKY).

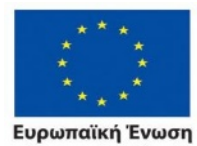

Eupwraïkń 'Evworn
Operational Programme Human Resources Development, Education and Lifelong Learning co-financed by Greece and the European Union

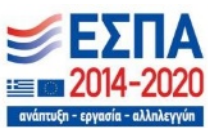

\section{Conflicts of Interest}

The authors declare no conflicts of interest regarding the publication of this paper.

\section{References}

Blustein, D., Ali, S., \& Flores, L. (2019). Vocational Psychology: Expanding the Vision and Enhancing the Impact. The Counseling Psychologist, 47, 166-221. https://doi.org/10.1177/0011000019861213

Bright, J. E. H., \& Pryor, R. G. L. (2011). The Chaos Theory of Careers. Journal of Employment Counseling, 48, 163-166. https://doi.org/10.1002/j.2161-1920.2011.tb01104.x

Brott, P. (2001). The Storied Approach: A Postmodern Perspective for Career Counseling. The Career Development Quarterly, 49, 304-313. https://doi.org/10.1002/j.2161-0045.2001.tb00958.x

Brott, P. (2004). Constructivist Assessment in Career Counseling. Journal of Career Development, 30, 189-200. https://doi.org/10.1177/089484530403000302

Bruner, J. S. (2002). Making Stories: Law, Literature, Life. Harvard University Press.

Bujold, C. (2004). Constructing Career through Narrative. Journal of Vocational Behavior, 64, 470-484. https://doi.org/10.1016/j.jvb.2003.12.010

Busacca, L. A., \& Rehfuss, M. C. (2017). Postmodern Career Counseling: A Handbook of 
Culture, Context, and Cases. American Counseling Association.

Cochran, L. (1990). The Sense of Vocation. State University of New York Press.

Cochran, L. (1997). Career Counseling: A Narrative Approach. Sage.

Del Corso, J., \& Rehfuss, M. C. (2011). The Role of Narrative in Career Construction Theory. Journal of Vocational Behavior, 79, 334-339. https://doi.org/10.1016/j.jvb.2011.04.003

Di Fabio, A. (2014). Career Counselling and Positive Psychology in the 21st Century: New Constructs and Measures for Evaluating the Effectiveness of Intervention. Journal of Counsellogy, 1, 193-213.

Gergen, K. (1985). The Social Constructivist Movement in Modern Psychology. American Psychologist, 40, 266-275. https://doi.org/10.1037/0003-066X.40.3.266

Guichard, J. (2005). Life-Long Self-Construction. International Journal for Educational and Vocational Guidance, 5, 111-124. https://doi.org/10.1007/s10775-005-8789-y

Guichard, J. (2009). Self-Constructing. Journal of Vocational Behavior, 75, 251-258. https://doi.org/10.1016/j.jvb.2009.03.004

Guichard, J. (2015). From Vocational Guidance and Career Counselling to Life Design Dialogues. In L. Nota, \& J. Rossier (Eds.), Handbook of Life Design: From Practice to Theory, from Theory to Practice (pp. 1-25). Hogrefe Publishing.

Guichard, J. (2018). Final Purposes for Life-and-Career Design Interventions in the Anthropocene Era. In V. Cohen-Scali, L. Nota, \& J. Rossier (Eds.), New Perspectives on Career Guidance and Counseling in Europe. Building Careers in Changing and Diverse Societies (pp. 189-204). Springer International Publishing.

https://doi.org/10.1007/978-3-319-61476-2 12

Hartung, P. J. (2015). Life Design in Childhood: Antecedents and Advancement. In L. Nota, \& J. Rossier (Eds.), Handbook of Life Design: From Practice to Theory and from Theory to Practice (pp. 89-102). Hogrefe.

Hartung, P. J., \& Santilli, S. (2018). My Career Story: Description and Initial Validity Evidence. Journal of Career Assessment, 26, 308-321.

https://doi.org/10.1177/1069072717692980

Holland, J. L. (1997). Making Vocational Choices: A Theory of Vocational Personalities and Work Environments. Psychological Assessment Resources.

Ibarra, H., \& Barbulescu, R. (2010). Identity as Narrative: Prevalence, Effectiveness, and Consequences of Narrative Identity Work in Macro Work Role Transitions. Academy of Management Review, 35, 135-154. https://doi.org/10.5465/AMR.2010.45577925

Issari, F. (2011). O eaftos ke I taftotita os dialogiki schesi ke politismiki afigisi (Self and Identity as a Dialogical Relationship and Cultural Narrative). In M. Pourkos (Ed.), Koinoniko-istoriko-politismikes proseggiseis stin Psychologia ke tin Ekpaidefsi (Socio-Historic-Cultural Approaches in Psychology and Education) (pp. 268-280). Diadrasi.

Issari, P., \& Karayianni, Th. (2013). Greek Mothers' Narratives of the Construct of Parental Involvement. The European Journal of Counselling Psychology, 2, 17-32. https://doi.org/10.5964/ejcop.v2i1.3

Kaliris, A., \& Kriwas, S. (2014). The Contribution of the Postmodern Approaches to Career Counseling Theory and Practice: Their Emerging Role in a Crucial Era for the World of Work. http://www.elesyp.gr/index.php/news/drastiriotites

Kriwas, S. (2011). I symvoli tou konstrouktivismou ke tou koinonikou konstrouksionismou sti symvoyleftiki gia ti stadiodromia: Theoretikes kai praktikes diastaseis (The Contribution of Constructivism and Social Constructionism to Career Counseling: 
Theoretical and Practical Dimensions). Epitheorisi Symvouleftikis ke Prosanatolismoy (Review of Counselling and Guidance), 96-97, 51-62.

Malikiosi-Loizos, M. (2017). Simvouleftiki Psichologia (Counseling Psychology). Pedio Publications.

Maree, J. G. (2015). Blending Retrospect and Prospect in Order to Convert Challenges into Opportunities in Career Counseling. In J. G. Maree, \& A. Di Fabio (Eds.), Exploring New Horizons in Career Counseling: Turning Challenge into Opportunities (pp. 4-24). Sense Publishers. https://doi.org/10.1007/978-94-6300-154-0 1

McIlveen, P. (2009). Career Development Practice and Career Counselling in Australia. Asian Journal of Counselling, 16, 113-132.

McIlveen, P., \& Patton, W. (2007). Narrative Career Counselling: Theory and Exemplars of Practice. Australian Psychologist, 42, 226-235. https://doi.org/10.1080/00050060701405592

McIlveen, P., McGregor-Bayne, H., Alcock, A., \& Hjertum, E. (2003). Evaluation of a Semi-Structured Career Assessment Interview Derived from Systems Theory Framework. Australian Journal of Career Development, 12, 33-41. https://doi.org/10.1177/103841620301200306

McLeod, J. (2003). An Introduction to Counselling (3rd ed.). Open University Press.

McMahon, M. (2014). New Trends in Theory Development in Career Psychology. In G. Arulmani, A. J. Bakshi, F. T. L. Leong, \& A. G. Watts (Eds.), Handbook of Career Development: International Perspectives (pp. 13-27). Springer Science + Business Media.

McMahon, M. (2018). Narrative Career Counselling: A Tension between Potential, Appeal, and Proof. Introduction to the Special Issue. Australian Journal of Career Development, 27, 57-64. https://doi.org/10.1177/1038416218785537

McMahon, M., \& Watson, M. (2010). Story Telling: Moving from Thin Stories to Thick and Rich Stories. In K. Maree (Ed.), Career Counselling: Methods That Work (pp. 53-63). Juta.

McMahon, M., \& Watson, M. (2012). Story Crafting: Strategies for Facilitating Narrative Career Counselling. International Journal for Educational and Vocational Guidance, 12, 211-224. https://doi.org/10.1007/s10775-012-9228-5

McMahon, M., Bimrose, J., Watson, M., \& Abkhezr, P. (2019). Integrating Storytelling and Quantitative Career Assessment. International Journal for Educational and Vocational Guidance, 20, 523-542. https://doi.org/10.1007/s10775-019-09415-1

McMahon, M., Patton, W., \& Watson, M. (2005). My System of Career Influences. Australian Council for Educational Research.

Patton, W., \& McMahon, M. (2014). Career Development and Systems Theory: Connecting Theory and Practice (3rd ed.). Sense Publishers. https://doi.org/10.1007/978-94-6209-635-6 1

Peake, S., \& McDowall, A. (2012). Chaotic Careers: A Narrative Analysis of Career Transition Themes and Outcomes Using Chaos Theory as a Guiding Metaphor. British Journal of Guidance \& Counselling, 40, 395-410.

https://doi.org/10.1080/03069885.2012.704350

Peavy, R. V. (1997). SocioDynamic Counselling: A Constructivist Perspective. Trafford Publishers.

Peavy, R. V. (2000). SocioDynamic Perspective and the Practice of Counselling (pp. 1-12). NATCON Papers.

Pryor, R. G. L., Amundson, N. E., \& Bright, J. E. H. (2008). Probabilities and Possibilities: The Strategic Counseling Implications of the Chaos Theory of Careers. The Career 
Development Quarterly, 56, 309-318.

https://doi.org/10.1002/j.2161-0045.2008.tb00096.x

Pryor, R., \& Bright, J. (2019). Careers as Fractal Patterns: The Chaos Theory of Careers Perspective. In N. Arthur, \& M. McMahon (Eds.), Contemporary Theories of Career Development: International Perspectives (pp. 135-152). Routledge. https://doi.org/10.4324/9781315276175-12

Reid, H. L., \& West, L. (2011). “Telling Tales”: Using Narrative in Career Guidance. Journal of Vocational Behavior, 78, 174-183. https://doi.org/10.1016/j.jvb.2010.10.001

Reid, H. L., \& West, L. (2014). Telling Tales: Do Narrative Approaches for Career Counseling Count? In G. Arulmani, A. J. Bakshi, F. T. L. Leong, \& A. G. Watts (Eds.), Handbook of Career Development: International Perspectives (pp. 413-430). Springer Science + Business Media. https://doi.org/10.1007/978-1-4614-9460-7 23

Rossier, J., Cardoso, P. M., \& Duarte, M. E. (2021). The Narrative Turn in Career Development Theories: An Integrative Perspective. In P. Robertson, T. Hooley, \& P. McCash (Eds.), The Oxford Handbook of Career Development (pp. 169-180). Oxford University Press. https://doi.org/10.1093/oxfordhb/9780190069704.013.13

Rudolph, C. W., Lavigne, K. N., \& Zacher, H. (2017). Career Adaptability: A Meta-Analysis of Relationships with Measures of Adaptivity, Adapting Responses, and Adaptation Results. Journal of Vocational Behavior, 98, 17-34.

https://doi.org/10.1016/j.jvb.2016.09.002

Savickas, M. (2005). The Theory and Practice of Career Construction. In S. D. Brown, \& R. W. Lent (Eds.), Career Development and Counseling: Putting Theory and Research to Work (pp. 42-70). John Wiley \& Sons.

Savickas, M. L. (2006). Counseling for Career Construction (Facilitating the Storied Approach in Career Counseling: Practical Implementation). In Fifteenth Australian Career Counseling Conference (Vol. 18).

Savickas, M. L. (2012). Life Design: A Paradigm for Career Intervention In the 21st Century. Journal of Counseling and Development, 90, 13-19. https://doi.org/10.1111/j.1556-6676.2012.00002.x

Savickas, M. L. (2015). Career Counseling Paradigms: Guiding, Developing, and Designing. In P. Hartung, M. Savickas, \& W. Walsh (Eds.), The APA Handbook of Career Interventions (pp. 129-143). APA Press. https://doi.org/10.1037/14438-008

Savickas, M. L. (2019). Career Counseling (2nd ed.). American Psychological Association. https://doi.org/10.1037/0000105-000

Savickas, M. L., \& Porfeli, E. J. (2012). Career Adapt-Abilities Scale: Construction, Reliability, and Measurement Equivalence across 13 Countries. Journal of Vocational Behavior, 80, 661-673. https://doi.org/10.1016/j.jvb.2012.01.011

Savickas, M. L., Nota, L., Rossier, J., Dauwalder, J. P., Duarte, M. E., van Vianen, A. E. M. et al. (2009). Life Designing: A Paradigm for Career Construction in the 21st Century. Journal of Vocational Behavior, 75, 239-250. https://doi.org/10.1016/j.jvb.2009.04.004

Sidiropoulou-Dimakakou, D., Mikedaki, K., Argyropoulou, K., \& Kaliris, A. (2018). A Psychometric Analysis of the Greek Career Adapt-Abilities Scale in University Students. International Journal of Psychological Studies, 10, 95-108. https://doi.org/10.5539/ijps.v10n3p95

Stebleton, M. J. (2010). Narrative-Based Career Counseling Perspectives in Times of Change: An Analysis of Strengths and Limitations. Journal of Employment Counseling, 47, 64-78. https://doi.org/10.1002/j.2161-1920.2010.tb00091.x

Watkins, C. E., \& Savickas, M. L. (1990). Psychodynamic Career Counseling. In W. B. 
Walsh, \& S. H. Osipow (Eds.), Career Counseling: Contemporary Topics in Vocational Psychology (pp. 79-116). Erlbaum.

Watson, M. (2016). Career Development in Changing World Contexts: Reconstructing the Wheels of Theory and Practice. CEAV (Career Education Association of Victoria) e-Journal, 43, 18. 